\title{
Groundwater Nitrate Contamination Risk Assessment: A Comparison of Parametric Systems and Simulation Modelling
}

\author{
${ }^{1}$ Dario Sacco, ${ }^{2}$ Marco Offi, ${ }^{2}$ Marina De Maio, ${ }^{1}$ Carlo Grignani \\ ${ }^{1}$ Dip. Agronomia, Selvicoltura e Gestione del territorio, Università di Torino, V. L. Da Vinci 44, \\ 10095 Grugliasco (TO), Italy \\ ${ }^{2}$ DITAG, Politecnico di Torino, C.so Duca degli Abruzzi 24, 10129 Torino, Italy
}

\begin{abstract}
Groundwater nitrate contamination is a source of rising concern that has been faced through the introduction of several regulations in different countries. However the methodologies used in the definition of Nitrate Vulnerable Zones are not included in the regulations. The aim of this work was to compare different methodologies, used to asses groundwater nitrate contamination risks, based on parametric systems or simulation modelling. The work was carried out in Piedmont, Italy, in an area characterised by intensive animal husbandry, high $\mathrm{N}$ load, a shallow water table and a coarse type of sub-soil sediments. Only N loads from agricultural non-point sources were considered. Different methodologies with different level of information have been compared to determine the groundwater nitrate contamination risk assessment: $\mathrm{N}$ load, IPNOA index, the intrinsic contamination risk from nitrates, leached $\mathrm{N}$ and $\mathrm{N}$ concentration of the soil solution estimated by the simulation model. The good correlation between the IPNOA index and the intrinsic nitrate contamination risk revealed that the parameters that describe the soil in this area did not lead to a different classification of the parcels.

The intrinsic nitrate contamination risk was greatly influenced by $\mathrm{N}$ fertilisation, however the effect of the soils increased the variability in comparison to the IPNOA index. The leached $\mathrm{N}$ and $\mathrm{N}$ concentration in the leaching were closely correlated. The dilution effect of percolated water was almost negligible. Both methodologies were slightly correlated to the $\mathrm{N}$ fertilisation and the two indexes. The correlations related to the intrinsic nitrate contamination risk was higher than those related to IPNOA, and this means that the effect of taking into account soil parameters increases the correlation to the prediction of the simulation model.
\end{abstract}

Keywords: Aquifer Vulnerability, GIS, IPNOA, N fertilisation, Simulation modelling

\section{INTRODUCTION}

Nitrate contamination of the groundwater throughout the world is a source of rising concern that has been faced through the introduction of several regulations in different countries.

The groundwater nitrate concentrations in Europe exceed the international recommendations for drinking water $\left(50 \mathrm{mg} \mathrm{N}-\mathrm{NO}_{3}^{-} 1^{-1}(1)\right)$, in $22 \%$ of cultivated land ${ }^{[2]}$. Similar concentrations have been found in the USA and in China ${ }^{[2]}$.

The Nitrate Directive in Europe $^{[3]}$ requires the implementation of measures to reduce nitrate leaching in water bodies. The Water Framework Directive ${ }^{[4]}$, which has recently been adopted in Italy $^{[5]}$, specifies future objectives to increase the quality not only of deep water, but also of surface water.
Agriculture is considered the main source of nitrate contamination in groundwater. Excessive use of chemicals and fertilizers increases the risk of groundwater contamination ${ }^{[6]}$.

The solution adopted in Europe consists in the definition of Nitrate Vulnerable Zones (NVZs), where the risk of $\mathrm{N}$ leaching in deep water bodies is high, and in the reduction of the amount of $\mathrm{N}$ fertilisers distributed over the fields, as this is considered to be the most effective measure to reduce groundwater contamination.

The methodologies used to define NVZs differs from country to country and in many cases they are not dictated by the regulations.

The Italian regulation ${ }^{[5]}$ suggests a parametric system based on empirical relationships between the soil or sub-soil characteristics and $\mathrm{N}$ leaching risk.

Corresponding Author: Marina De Maio, DITAG (Dipartimento del Territorio, dell'Ambiente e delle Geotecnologie) Politecnico di Torino, c.so Duca degli Abruzzi 24, 10129 - Torino, Italy 


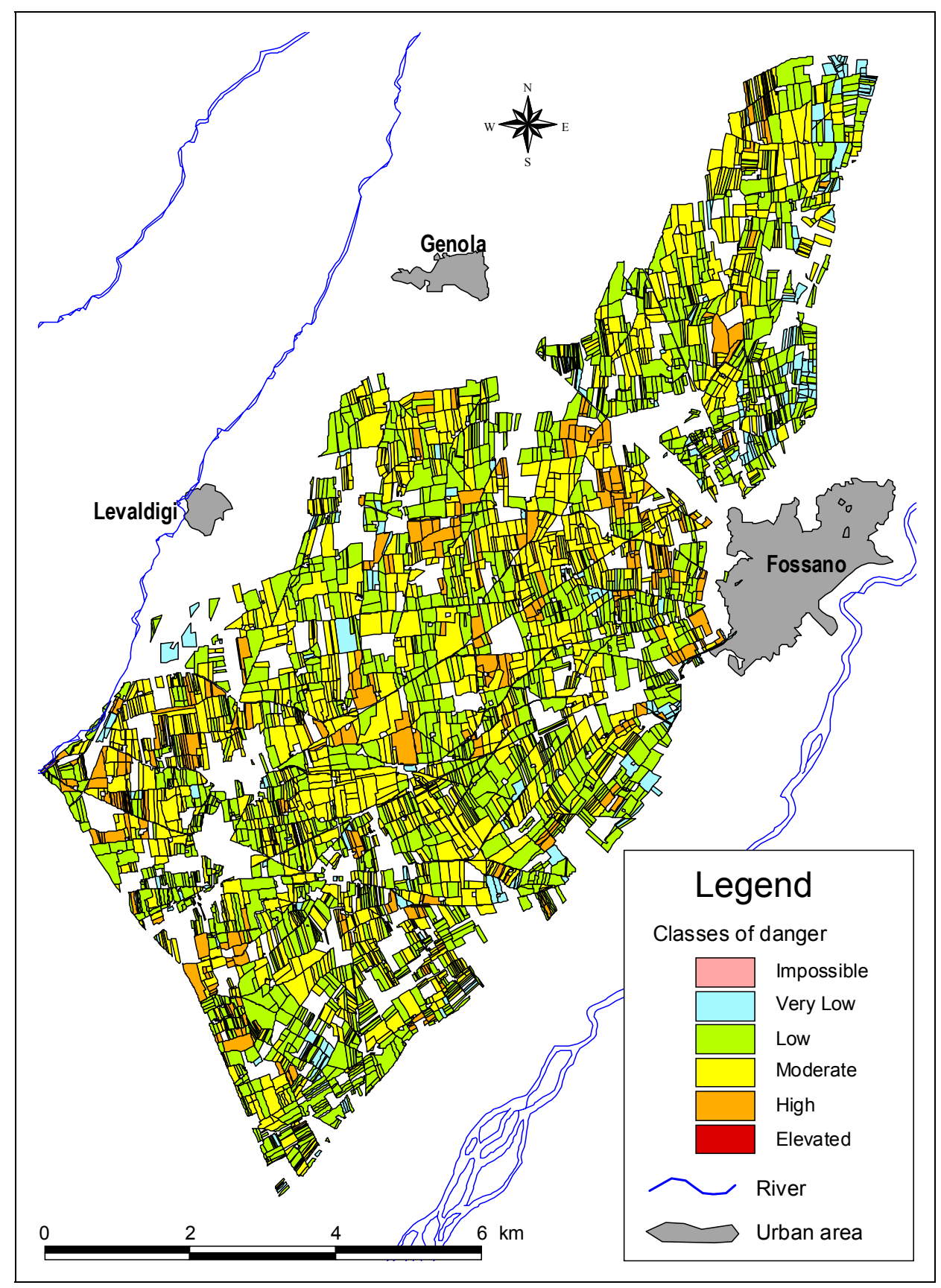

Fig 1:. Map of the IPNOA index of nitrate hazard in the Fossano area.

Similar methods are usually designed to be applied over large scales and the availability of the input is one of the main requirements considered at a design level. Others are based on simulation models aimed at simulating soil-plant-atmosphere dynamics. Many of them are produced for scientific purposes and the availability of input is not one of the objectives of their design. They are usually very complex and require information about the climate, the soil and the plant physiology.
The models that are considered here only refer to water and nitrogen dynamics.

Examples of regional applications of these models are reported by many authors ${ }^{[7,8]}$. The reliability of the results is closely related to the quality of the input. They are usually firstly evaluated at a field or soil column scale and then they are upscaled to a region.

The aim of this work was to compare the application of different methodologies aimed at groundwater nitrate contamination risk assessment, based on parametric systems or based on simulation modelling. 


\section{MATERIALS AND METHODS}

The area: The work was carried out in a 7773 ha area in the Western Po plain (Piedmont, Italy). This area was chosen because it is characterised by intensive animal husbandry and might soon be designated as a NVZ ${ }^{[3]}$. The high $\mathrm{N}$ load, the shallow water table and the coarse type of sub-soil sediments contribute to the vulnerability from $\mathrm{N}$ leaching. Only $\mathrm{N}$ loads derived from agricultural non point sources have been considered in this work. A complete description of the agricultural aspects of the area and of the soil can be found in Sacco et al ${ }^{[9]}$.

The information concerning the land use, the agricultural practices and fertilisation was derived from a Geographical Information System at the scale of a cadastral parcel ${ }^{[9]}$. The information about the soils and the water table depth have already been presented in Sacco et al. ${ }^{[10]}$.

From a hydrogeological point of view, the only complex outcropping in the study area is the Main Alluvial Complex, which belongs to the quaternary sequence. It is characterized by gravel with a poor silty matrix, ranging in thickness from 20 to 40 meters and with a generally moderate to high permeability which is correlated to the percentage of the silty matrix. An Altered Gravels Complex can be found under this complex, belonging to the Plio-Pleistocenic series and formed by altered gravels in an abundant fine matrix (silt to clay), with rather low relative permeability.

The Main Alluvial Complex encompasses an unconfined aquifer which has a rather uniform flow pattern, with a SW-NE direction and with a hydraulic gradient equal to $0.5 \%$. The water table depth is maximum in the South $(12 \mathrm{~m})$ and it decreases moving towards the North, reaching the surface NE of Fossano. The groundwater nitrate contamination risk assessment The N load

$\mathrm{N}$ fertilisation represents the basic level of information, even though a great deal of effort is required to obtain this kind of data. In Italy, official databases usually do not provide reliable information about $\mathrm{N}$ fertilisation and interviews with local experts were required ${ }^{[9]}$. However, such data represents the information that is necessary for all the methodologies.

\section{The parametric systems:}

The intrinsic nitrate contamination risk from Agricultural sources has been evaluated through the synergic application of two parametric methods: IPNOA $^{[11,12]}$ and SINTACS ${ }^{[13]}$. IPNOA determines the hazard of nitrate contamination from agricultural sources, according to D.Lgs $152 / 06^{[5]}$, while SINTACS determines the aquifer vulnerability to contamination, as defined by Civita ${ }^{[14]}$.

IPNOA divides the different factors that determine the total index of the $\mathrm{N}$ load into two groups: the hazard factors (FP), which contribute to the nitrate load on the soil and the control factors (FC), which amplify or decrease the effect of such a load. The three FPs are mineral fertilization, organic fertilization and depuration sludge. The four FCs are total $\mathrm{N}$ content in the soil, type of climate, agronomic practices and irrigation type.

A score is assigned to each cadastral parcel for each FP and each FC.

The IPNOA index is obtained from the sum of the three FPs multiplied by the product of the four FCs. The final values of each cadastral parcel is classified in six classes which represent six degrees of nitrate contamination hazard from agricultural sources.

SINTACS requires the discretization of the area into 50 by $50 \mathrm{~m}$ wide square cells, and then a score for each of the followings seven parameters is assigned to each cell: depth-to-water, amount of infiltration through the soil, physical characteristics of the unsaturated zone, soil texture, hydrogeologic characteristics of the aquifer, hydraulic conductivity of the aquifer and topographic slope.

The scores assigned to the seven parameters produce a vector of scores. This vector of scores is multiplied by a string of multiplier weights related to the effective hydrogeologic and impacting situation into which each cell falls (normal impact, relevant impact, drainage from surface water network, occurrence of deep karstified terrain and fissured terrain). The sum of the products gives the SINTACS index. A SINTACS index was assigned to each cadastral parcel choosing the highest class falling inside each cadastral parcel. The vulnerability degree is derived from the normalization and categorization of the SINTACS index into six vulnerability classes.

The product of the SINTACS index multiplied by IPNOA index, calculated for each parcel and again categorized into six classes, represents the intrinsic nitrate contamination risk from agricultural sources.

The results are used to draw a thematic Map, which is useful as a decision support tool for water management or agricultural planning.

\section{The simulation model:}

The simulation model chosen was CropSyst 3.04.08 because of its capability to study the effects of climate, soils, and management on cropping system productivity and the environment ${ }^{[15]}$. It has already been tested in similar environments ${ }^{[8,16,17]}$. CropSyst is a multi-year, daily time step, multi-crop model with a mechanistic approach to the simulation of the soil-water-plantatmosphere system, crop growth and yield. The model includes several agronomic management options such as irrigation, nitrogen fertilization, tillage, residue management, cultivar and rotation selection. It also has environmental impact analysis capabilities through erosion and chemical leaching calculations ${ }^{[18]}$. 


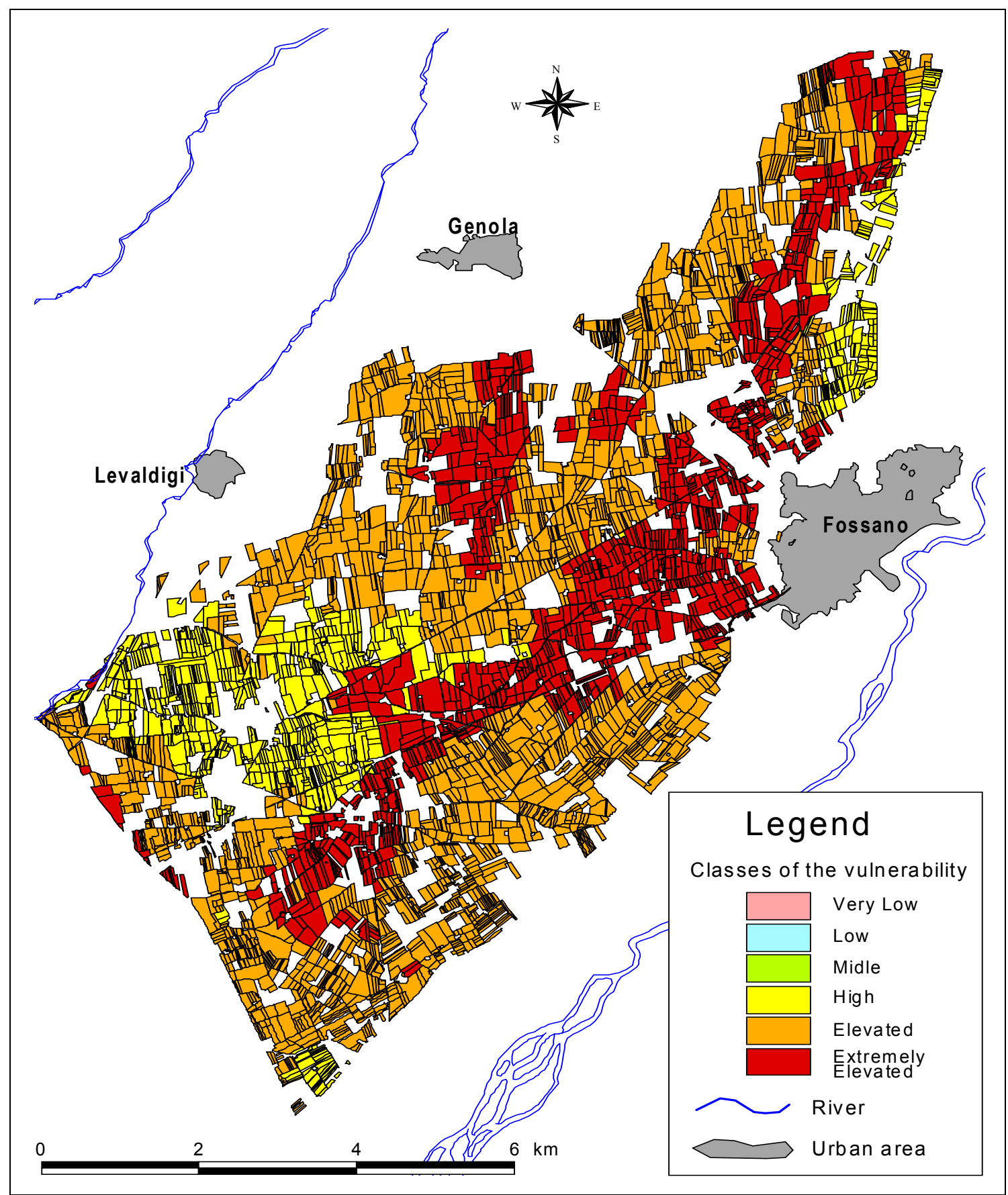

Fig 2:. Map of the aquifer vulnerability in the Fossano area.

Its ability to simulate cropping systems in situations where the water table is particularly shallow has been demonstrated by Sacco et al. ${ }^{[19]}$. The results of the simulation, at a territorial scale, have already been published by Sacco et al. ${ }^{[10]}$.

Based on this findings a simulation was performed for each cadastral parcel for a period corresponding to 1988 $-1999$.

The outputs of the model, that where considered in this work as indicators of the different degrees of nitrate contamination risk, were the amount of nitrogen leached and the nitrate concentration in the leached soil solution. Where the water table was shallower than $5 \mathrm{~m}$, the output of the model was calculated at the water table depth. Where the water table was deeper than $5 \mathrm{~m}$, the output of the model was calculated at the bottom of the soil profile. In this case the chemical or biological transformations of the $\mathrm{N}$ between the bottom of the profile and the water table were not considered. 


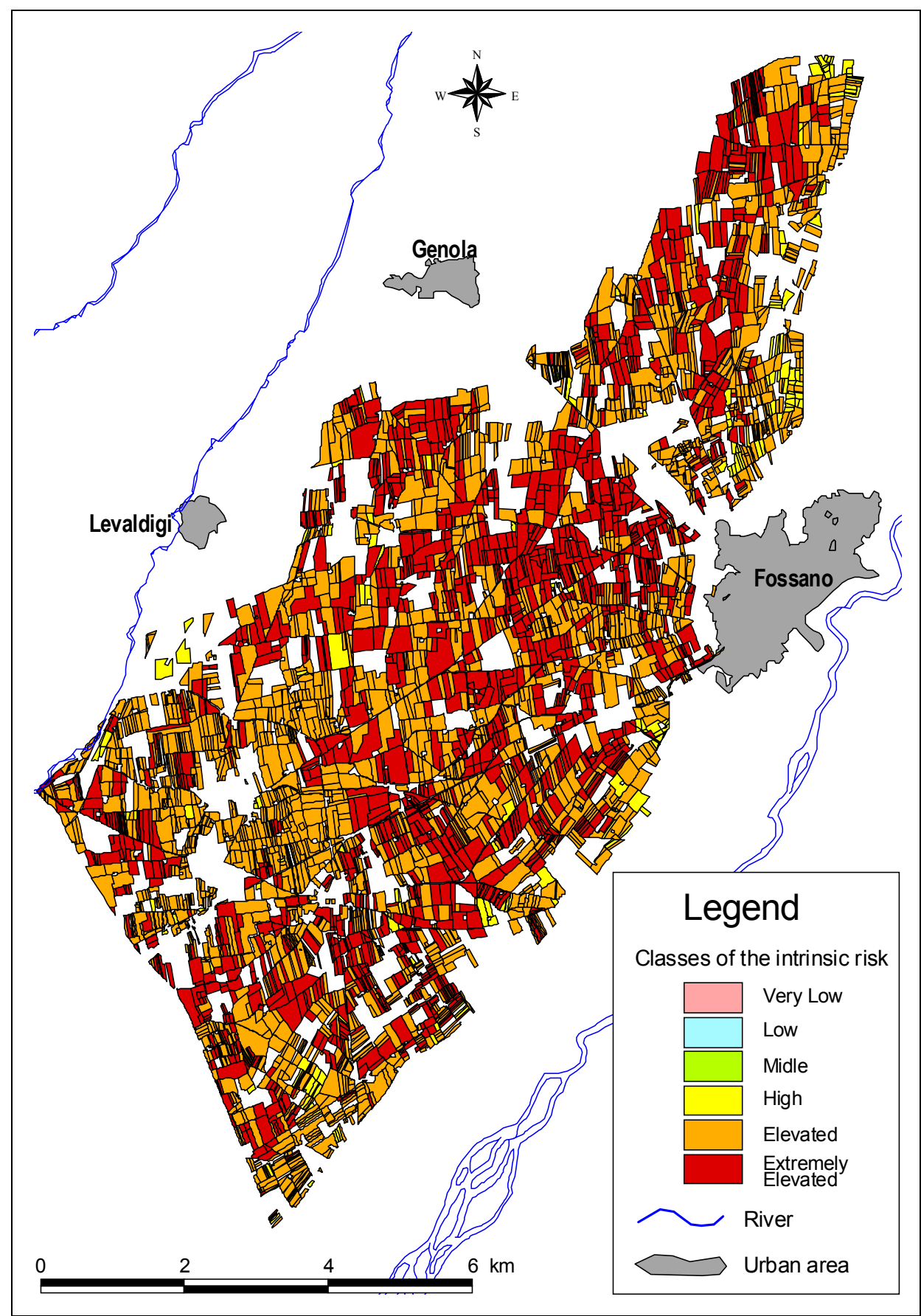

Fig 3: Map of the intrinsic nitrate contamination risk from Agricultural sources in the Fossano area.

The values refer to the average of the 12-year period for each cadastral parcel.

Data analysis: The IPNOA index and the intrinsic nitrate contamination risk from agricultural sources are categorical data. Because of this, their distribution does not follow a normal distribution. The leached $\mathrm{N}$, the $\mathrm{N}$ concentration in leaching and the total $\mathrm{N}$ fertilisation were tested for normality. All of them resulted to be
Non parametric statistics were used in the analysis of the data. Whenever the distance between the estimated value of leached $\mathrm{N}$ and its median was greater than 1.5 times the interquartile range, the data was considered an outlier and was removed from the dataset. Correlation analysis was performed between the different methodologies using the Sperman rho non parametric procedure $^{[21]}$. The distribution of the values in each category was represented using boxplots. 


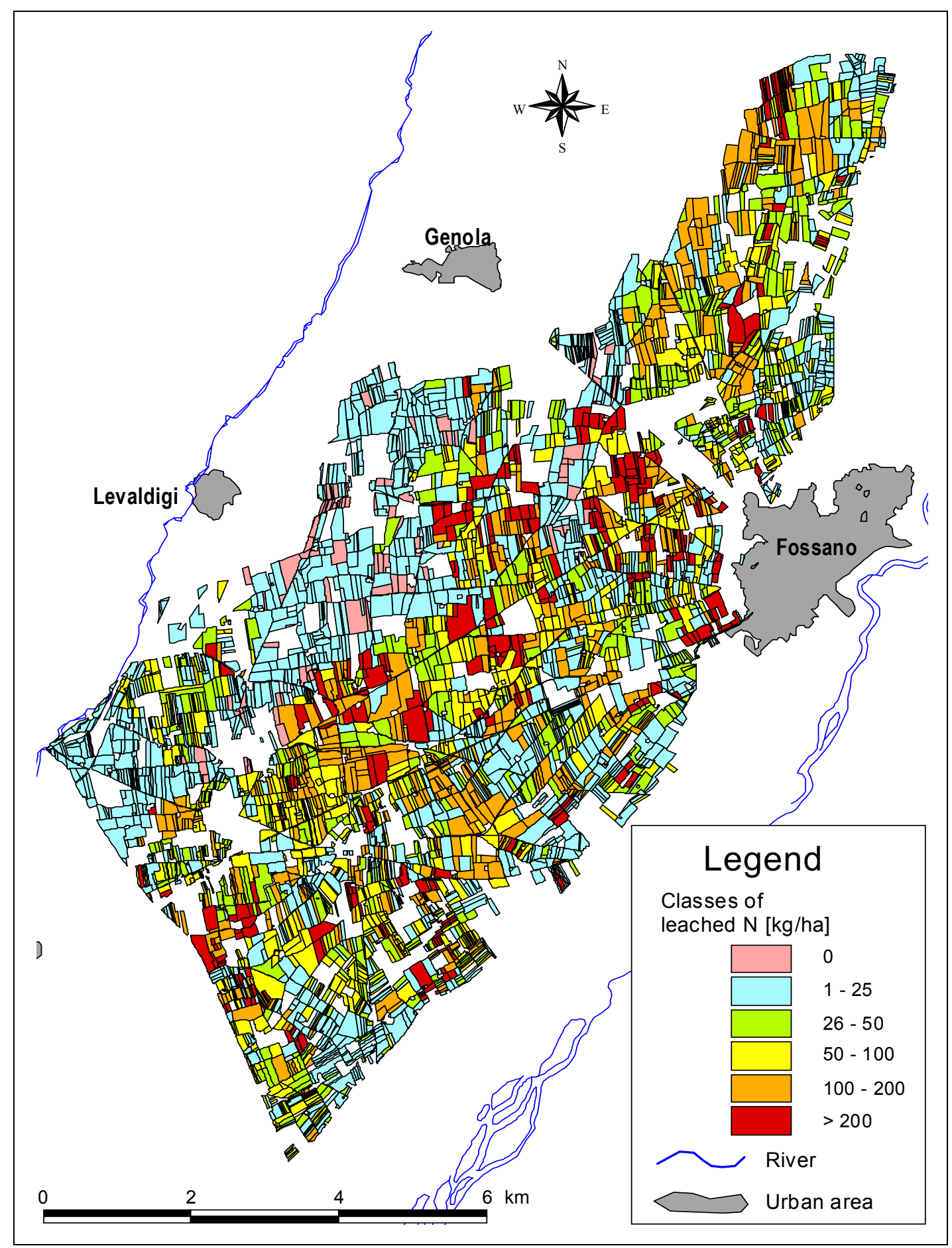

Fig 4: Map of the leached $\mathrm{N}$ estimated by Cropsyst in the Fossano area

\section{RESULTS AND DISCUSSION}

Figures 1, 2 and 3 show the IPNOA index, the SINTACS index, and the intrinsic nitrate contamination risk from Agricultural sources. As far as the IPNOA index is concerned, it is remarkable that around $85 \%$ of the area falls into the Moderate (class 3) and High (class 4) classes, $10 \%$ into Elevated (class 5) class and the remaining $5 \%$ in the Low (class 2) class. The situation highlighted by the intrinsic risk Map (Figure 3 ) is more critical than the IPNOA index Map, as more than $95 \%$ of the studied area falls into the Extremely Elevated (class 6) or Elevated (class 5) classes, and this increase is linked to the degree of vulnerability which 
also results to be Extremely Elevated or Elevated, over the whole area.

Figure 4 reports the values of leached $\mathrm{N}$ estimated by the simulation model. The results depend on a combination of many variables. However, the lower values in the Map can be observed in the Western and North Western part of the area, where hydraulic conductivity of the soil is lower, while higher values can be observed in Northern part of the area where water table is shallower.

Figure 5 represent the frequency distributions of the cadastral parcels in the classes of the different methodologies over the area.

Table 1 reports the results of the non parametric correlation analysis (Sperman rho) between the different variables.

All the correlations resulted to be highly significant with positive correlation coefficients ranging from 0.27 to 0.88 . The IPNOA index and the intrinsic nitrate contamination risk from Agricultural sources resulted to be well correlated and to $\mathrm{N}$ fertilisation. Lower values of correlation coefficients were found for the leached $\mathrm{N}$ and $\mathrm{N}$ concentration in leaching, even though the correlation coefficients were higher for the intrinsic nitrate contamination risk from Agricultural sources than for the IPNOA index. The leached $\mathrm{N}$ and $\mathrm{N}$ concentration in leaching resulted to be well correlated while the correlation coefficient against the $\mathrm{N}$ fertilisation was lower for both variables than those calculated for the IPNOA index and the intrinsic nitrate contamination risk from Agricultural sources.
Figures 6 and 7 report the boxplots of the distribution of the different values of leached $\mathrm{N}$ in the different classes determined according to the IPNOA index and the intrinsic nitrate contamination risk from Agricultural sources. The upper limit of boxes, which include 50\% of the cases in each class, increased, increased with an increase of the IPNOA class. The lower limits of the boxes remain almost constant throughout the classes.

The different Maps show the results of the different indexes at a regional level.

The Maps of the intrinsic nitrate contamination risk from Agricultural sources was derived from a combination of the other two Maps and the variability of its results is difficult to explain because it combines different sources. The variability of the IPNOA index mainly depends on the Maps of the $\mathrm{N}$ load, which is quite variable over the area, as it depends on the cultivated crop and on the amount of organic fertiliser available on the farm.

The aquifer vulnerability resulted to be high in the Southern part of the area, owing to the presence of a deep water table and in the North Eastern part of the area, due to the low hydraulic conductivity of the soil and to the high soil organic matter content, even though the water table is particularly shallow in these two areas.

The aquifer vulnerability resulted to be extremely elevated where the soil organic matter content was the lowest and the hydraulic conductivity of the soil the highest.

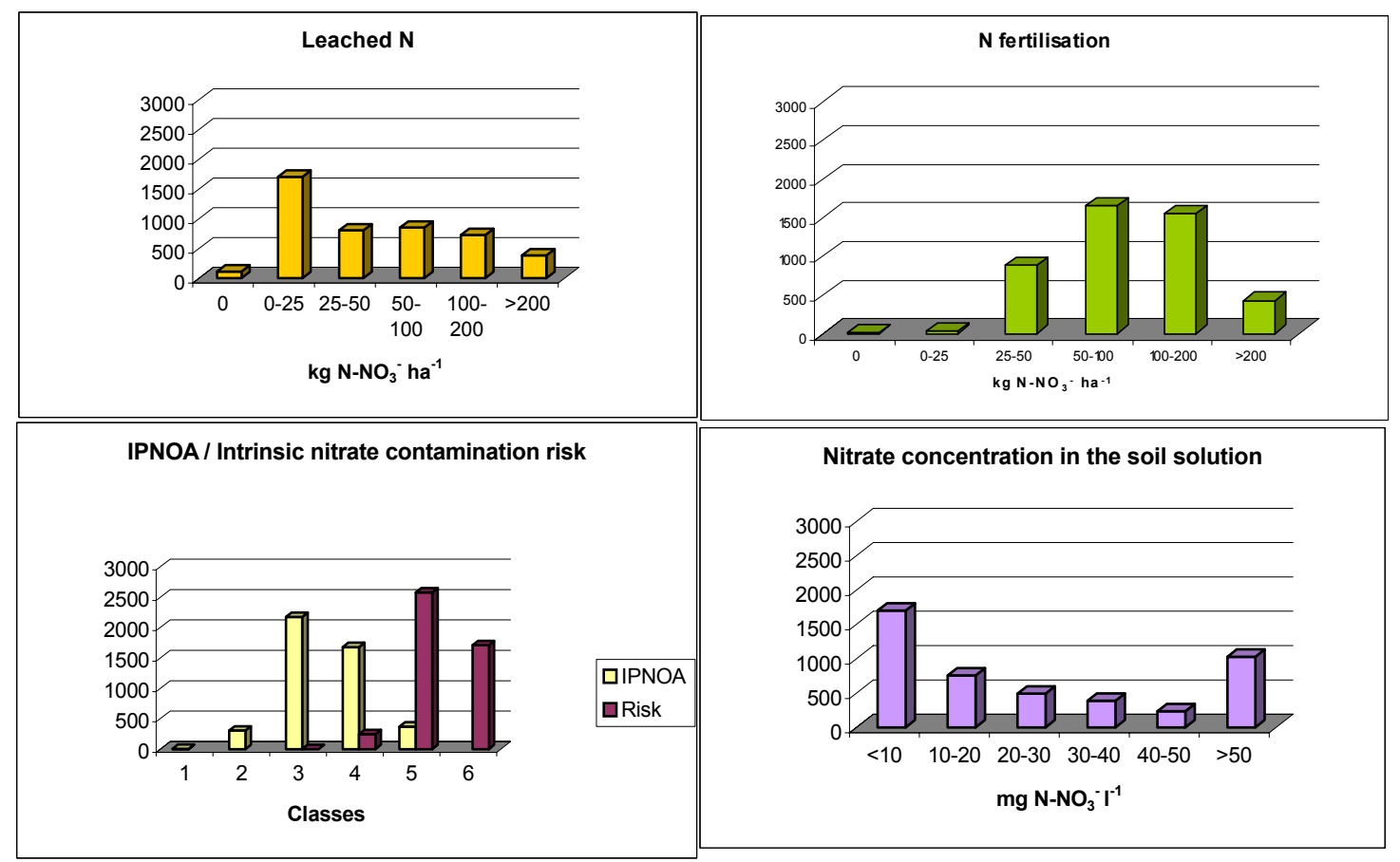

Fig 5: Frequency distributions of the cadastral parcels in the classes of the different methodologies. 


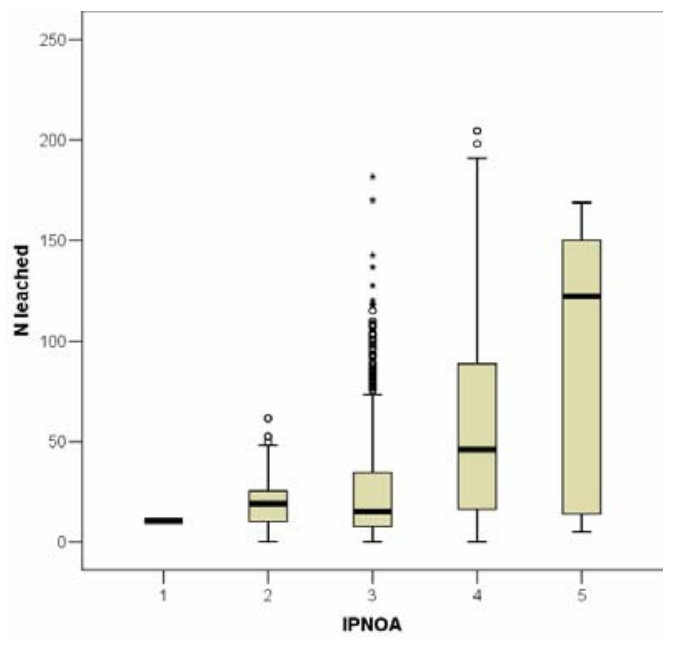

Fig 6: Amount of leached $\mathrm{N}$ in the different Ipnoa index classes. The values of leached $\mathrm{N}$ are in $\mathrm{kg} \mathrm{N} \mathrm{ha}{ }^{-1}$.

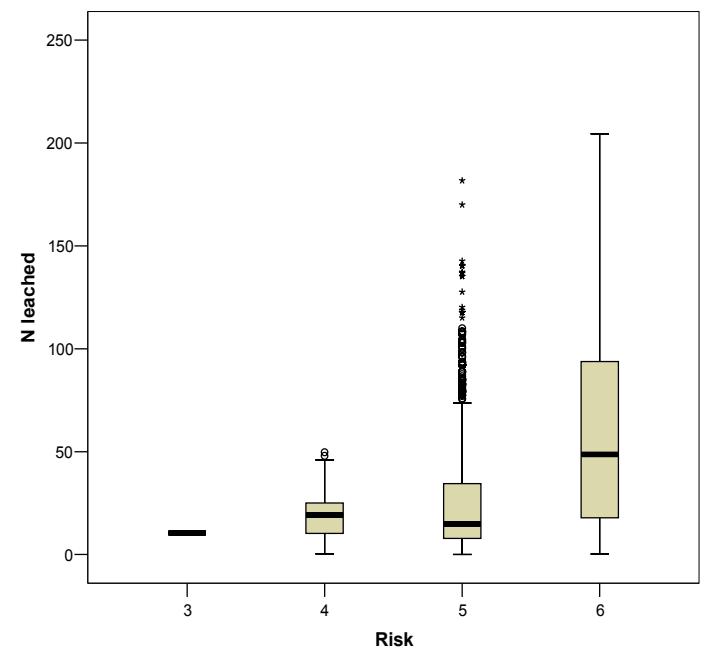

Fig 7: Amount of leached $\mathrm{N}$ in the different intrinsic contamination risk from nitrates (Risk) classes. The values of leached $\mathrm{N}$ are in $\mathrm{kg} \mathrm{N} \mathrm{ha}^{-1}$.

The leached $\mathrm{N}$ also showed a variability due to the variability of the $\mathrm{N}$ fertilisation in the different parcels. The different values of the soil hydraulic conductivity also influence the results of the simulation models as did the vulnerability results.

The good correlation between the IPNOA index and the intrinsic nitrate contamination risk from Agricultural sources revealed that, in this area, the parameters that describe the soil lead to a classification of the groundwater nitrate contamination risk of the parcels that is similar to those assigned by the IPNOA index, the latter only taking into account aspects related to agricultural practices. However, the ranking of the two indexes is not the same for the different parcels as the correlation coefficient is different from 1 .
The amount of fertiliser distributed on the soil was tested against the results of the other more complex methodologies to asses the reliability at the simpler level of information. The correlation of the $\mathrm{N}$ load against the other variables was also considered in order to evaluate the effectiveness of the regulations based on the reduction of fertilisation.

Table 1: Correlation analysis (Sperman rho) between the different variables. $\mathrm{N}=3865$. The Ipnoa and the intrinsic nitrate contamination risk from Agricultural sources (Risk) are number; leached $\mathrm{N}$ and $\mathrm{N}$ fertilisation are in $\mathrm{kg} \mathrm{N} \mathrm{ha}^{-1} \mathrm{y}^{-1} ; \mathrm{N}$ concentration in leaching is in $\mathrm{mg} \mathrm{N} \mathrm{l}^{-1}$.

Ipnoa Risk Leached N concentration in leaching

\begin{tabular}{lccccc} 
Risk & Corr. & 0.875 & & \\
& Sig. & 0.000 & & \\
& & & & & \\
Leached N & Corr.. & 0.315 & 0.349 & & \\
& Sig. & 0.000 & 0.000 & & \\
N concentration & Corr. & 0.271 & 0.317 & 0.881 & \\
in leaching & Sig. & 0.000 & 0.000 & 0.000 & \\
& & & & & \\
N fertilisation & Corr. & 0.856 & 0.739 & 0.352 & 0.311 \\
& Sig. & 0.000 & 0.000 & 0.000 & 0.000 \\
\hline
\end{tabular}

The IPNOA index was greatly influenced by the $\mathrm{N}$ fertilisation, as expected, as this is one of its components. The intrinsic nitrate contamination risk from Agricultural sources was also greatly influenced by $\mathrm{N}$ fertilisation, however the effect of the soils introduced variability in comparison to the IPNOA index..

The leached $\mathrm{N}$ and $\mathrm{N}$ concentration in leaching were highly correlated. In the model output, a large amount of leached $\mathrm{N}$ corresponded to a high concentration in the soil solution that left the soil. The variability in $\mathrm{N}$ concentration, due to different dilution effects of water percolated at the bottom of the profile or into the water table, was almost negligible. Both the model outputs were slightly correlated to the $\mathrm{N}$ fertilisation. The many processes simulated by the model provide different pathways for the $\mathrm{N}$ which does not necessary have to move downward towards the water table, but can also be uptaken by the plants or lost into the atmosphere.

Both models outputs are slightly correlated to the two indexes. The correlation coefficients related to the intrinsic nitrate contamination risk from Agricultural sources is higher than those related to the IPNOA index, which means that the effect of taking into 
account soil parameters increases the correlation to the prediction of the simulation model.

The reason for this slight correlation is the presence of low values of leached $\mathrm{N}$ in all the classes. This presence highlight the protective tendency of the two indexes.

\section{ACKNOWLEDGMENTS}

This project was funded by Regione Piemonte, Assessorato Ambiente, parchi e aree protette, risorse idriche, acque minerali e termali, energia and Assessorato Agricoltura, tutela della fauna e della flora.

\section{REFERENCES}

1. WHO, 1993. Guidelines for Drinking Water Quality. 1. Recommendations, 2nd Edition. World Health Organisation, Geneva.

2. Laegreid, M., Bockman, O.C., Kaarstad, O., 1999. Agriculture, fertilizers and the environment. Norsk Hydro ASA, Porsgrunn, Norway. CABI Publishing, pp 294.

3. EEC, European Economic Community, 1991. Council Directive concerning the protection of waters against pollution caused by nitrates from agricultural sources. Official Journal of the European Communities, 91/676/EEC

4. EC, European Community, 2000. Directive of the European Parliament and of the Council of 23 October 2000 establishing a framework for Community action in the field of water policy. Official Journal of the European Communities, 2000/60/EC

5. Italia, Decreto legislativo 3 aprile 2006, n. 152 Norme in materia ambientale. Gazzetta Ufficiale $\mathrm{n}$. 88 del 14 aprile 2006

6. Cepuder, P., Shukla, M.K., 2002. Groundwater nitrate in Austria: a case study in Tullnerfeld. Nutrient Cycling in Agroecosystems, 64, 301-315.

7. Hartkamp, A.D., White, J.W., Rossing, W.A.H, van Ittersum, M.K., Bakker, E.J., Rabbinge, R., 2004. Regional application of a cropping systems simulation model: crop residue retention in maize production systems of Jalisco, Mexico. Agricultural Systems, 82, 117-138.

8. Bechini, L., Bocchi, S., Maggiore, 2003. Spatial interpolation of soil physical properties for irrigation planning. A simulation study in northern Italy. European Journal of Agronomy, 19, 1-14

9. Sacco, D., Bassanino, M., Grignani, C., 2003a. Developing a regional agronomic information system for estimating nutrient balances at a larger scale. European Journal of Agronomy, 20, 199210 .
10. Sacco, D., Zavattaro, L., Grignani, C., 2007. Regional-scale predictions of agricultural $\mathrm{N}$ losses in an area with a high livestock density. Italian Journal of Agronomy (in press).

11. Padovani, M. Trevisan \& Capri E. 2000. Non point-source agricoltural hazard index: a case study of the province of Cremona. Environmental Management, 26, 577-584.

12. Padovani \& M. Trevisan 2002. I nitrati di origine agricola nelle acque sotterranee, Pitagora Editrice Bologna 103 pp.

13. Civita M., De Maio M. et al., 2003. Valutazione e catografia automatica della vulnerabilità degli acquiferi all'inquinamento con il sistema parametrico SINTACS R5 a new parametric system for the assessment and automatic mapping of ground water vulnerability to contamination. Pitagora Editrice. 200 pp.

14. Civita M., 1987. La previsione e la prevenzione del rischio di inquinamento delle acque sotterranee a livello regionale mediante le Carte di vulnerabilità. Atti Conv. "Inquinamento delle acque sotterranee :Previsione e prevenzione" Mantova, pp. 9-18.

15. Stöckle, C.O., Donatelli, M., Nelson, R., 2003. CropSyst, a cropping systems simulation model. European Journal of Agronomy, 18, 289-307

16. Donatelli, M., Stöckle, C.O., Ceotto, E., Rinaldi, M., 1997. Evaluation of CropSyst for cropping system at two location of northern and southern Italy. European Journal of Agronomy, 6, 35-45.

17. Morari, F., Lugato, E., Borin, M., 2004. An integrated non-point source model-GIS system for selecting criteria of best management practices in the Po Valley, North Italy. Agriculture, Ecosystems and Environment, 102, 247-262.

18. Peralta, J.M., Stöckle, C.O., 2001. Dynamics of nitrate leaching under irrigated potato rotation in Washington State: a long-term simulation study. Agriculture, Ecosystems and Environment 88, 2334.

19. Sacco, D., Stöckle, C.O., Zavattaro, L., 2001. Modelling water balance in shallow watertable areas. In: Proceedings "2 nd International Symposium Modelling Cropping Systems", 16-18 July, Florence, Italy, 85-86.

20. L.J. Bain, M. Engelhardt, Introduction to Probability and Mathematical Statistics, 2nd ed., Duxbury Press, California, 1992.

21. Siegel, S. 1956. Nonparametric statistics for the behavioral sciences. New York: McGraw-Hill. 